\title{
Determinants of Capital Structure of Listed Agro Firms in Nigeria
}

\author{
Nsika E. Bassey* \\ (nebass2005@yahoo.com)

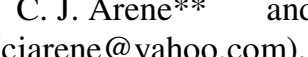 \\ Lecturer, Department of A \\ Nigeria \\ ** Department of Agricultural Economics, University of Nigeria, Nsukka \\ $* * *$ \\ Centre for Entrepreneurship and Development Research, University of Nigeria
}

\begin{abstract}
This paper examines the determinants of capital structure of agro-listed firms in Nigeria, using data generated from the financial statements of twenty eight (28) agro-allied firms, which have been listed in the Nigeria Stock Exchange (NSE) from 2005 to 2010. The major tool for data analysis was Ordinary Least Squares (OLS), which was used to analyze the identified firm-specific variables that affect short and long term debt ratios. All measured capital structure were scaled by the book value of total assets. In terms of short term debt ratio, large firms were perceived to have enough tangible assets at their disposal to pledge as collateral and access debt capital. Highly tangible firms also use more short-term debts, as high tangible asset reduced the magnitude of debt loss incurred by debt providers if the firms default. Growing listed firms used more short term debts, presumably due to their huge capital requirement for financing new short term investment opportunities and the need to meet current liabilities and other overhead expenses. Growing firms are presumed to lack both tangible assets and cheap long term credit sources of information and as such depends mostly on short term debts. The result further shows agro-listed firms with high taxes use more short term debts in their finances. Highly profitable firms do not depend on short-term debts, as they are perceived to be liquid enough to finance their short term investment through retained earnings at the expense of taking short term debts. In terms of long term debt ratio, highly profitable firms use less long term debts, implying that they have enough internally generated funds for their financing needs at the expense of borrowing. Large sized firms depend on long term debt for their finances because of high tangible assets at their disposal as collaterals. Firm age was positively related to long term debt ratio. The estimated growth coefficient was positively and significant, implying that growing firms use more long term debts. Finally, asset structure was found to be positively related to long-term debt ratio. Firms with high tangible assets are perceived to use more long term debts. It is recommended among others that appropriate protectionist policy be put in place for agro-based listed firms seeking short-term financing.
\end{abstract}

Keywords: capital structure, listed Agrofirms, finance, Nigeria

\section{Introduction}

Prior to Independence, agricultural production was the primary activity and the most prominent sector of Nigerian economic. It accounted for 65 percent of GDP (Yesufu, 1996) and provided the bulk of foreign exchange needed through export of agro based products. Manufacturing units that were established were mostly agro based firms and limited to primary production of raw materials for export. With the advent of petroleum oil some decades ago, Nigerian economy became entirely crude oil driven which is prone to world price shocks. As a result, the agricultural sector has been experiencing poor investment performance. For instance, its contribution to GDP drop from 61\% in 1960 to $7 \%$ in the 1960s (Oyedipe, 2008; Umar,2008). According to CBN (2006), agricultural contribution to GDP grew by $6.2 \%$ within 1981 - 1991 and by 3\% between $1991-2001$, implying a declining growth rate. Ijaiya (2000) and Iwayemi (1994) attributed this dismal performance of the agricultural sector to the discovery of petroleum oil. This has manifested in fluctuating profit after tax, reduction in corporate social responsibilities and declining share holder's funds in most agro firms. As a result, most of them have gone into liquidation while others resort to staff retrenchment, thereby further compounding the perennial problem of unemployment alongside her associated social vices

Apart from oil discovery unplanned capital structure and poor financing decisions have also been identified as some of the causative factor. This is so because the rate at which capital is borrowed has serious implication on the earning capacities of businesses (Pandey, 1999). Beyond this, corporate financing decisions have been found to be associated with a wide range of policy issues (Abor, 2008). For instance, at the macro level, they have implication for capital market development, interest rate and security price determination and regulation. At the micro level, such decision affects capital structure, corporate governance and company development (Green et al 2002). This, therefore, makes the financial mix decision of firms a vital one, given that where the rate of returns on the owner's equity is lower than the interest rate of borrowed funds, the value of the firm inevitably declines. It also, justifies making capital structure study a focal point in developing countries researches. 
In spite of these, numerous studies on corporate capital structure in developing countries still adopt data from developed countries ( see Rajan and Zingales (1995) ; Bevan and Danbolt (2002); Antoniou et al (2002) while Hall, Hutchinson \& Michalas (2004). Few ones such as Chen (1992), Booth et al (2001), Singh and Hamid (1992), Singh (1995), Pandey (2001), Abor (2008), Ezeoha (2011),Simon-Oke and Afolabi (2011),Iwarere and Akinnleye (2010) etc which utilized data from developing countries do not agree on the basis of their findings. As pointed out by Abor (2008), different countries have different institutional arrangement, mainly with respect to their tax and bankruptcy codes, the existing market for corporate control, the roles of banks and securities markets as well as their socio- cultural issues and their level of economic development. These differences, therefore, renders the study on the capital structure of developing countries and Nigeria, in particular, as a separate entity imperative.

In Nigeria, studies on capital structure are few and none have considered the agro- allied sector independently considering the enormous roles played by this sector in the country's economic development history (Arene and Ndomadu, 1997). Therefore, to fully comprehend how Agro firms finance their operations, knowledge of their capital structure becomes indispensable and warrants this study. Against this backdrop, the study examines the determinants of capital structure of agro listed firms in Nigeria.

\section{THEORETICAL FRAMEWORK}

Among the competing theories in explaining a firm's capital structure choices are;

\section{The static trade off theory}

The Static trade off theory also called the tax based theory was developed by Myers (1984) and proposes that firm's target leverage is driven by taxes, bankruptcy cost and agency conflicts. This theory explains the firm's capital structure in terms of exposure of the firm to bankruptcy and agency cost against the tax benefit associated with the use of debt. Green et. al (2002) \& Abor,(2008) have acknowledge the effect of tax policy on capital structure of firms. In their opinion, the advantages associated with leverage would lead firms to be completely financed through debt since corporate taxes allow firm to deduct interest on debt in computing taxable profit. However, some empirical evidences in support of this theory have been found. For instance, Kayhan \& Titman (2007) argued that firm at a long run tend to move towards target debt that is consistent with this theory. Amid the aforementioned evidence, some researchers such as Myers (2001) have pointed out some problem areas in the theory's inability to explain firm's actual behavior. For instance, the trade off theory suggests that highly profitable firms should have high debt ratio so as to shield their large profits from taxation, but Myers (2001) argued that in reality, highly profitable firms tend to have less debt than less profitable firms. Also, according to Cheng \& Jiang (2001), the theory claims that the optimal level of a firm's debt is achieved by weighing debt financing against the cost of potential financial distress. But, it is argued from the dynamic viewpoint that optimal leverage level can change due to changes in a firm's profitability level, non debt tax shield etc, therefore, even though a firm debt ratio changes in yearly basis, the theory cannot be rejected because the optimal leverage level itself may differ over time. Hence, the theory therefore offers one possible explanation of how firms choose their capital structures.

\section{The agency cost theory}

The classical agency theory was developed by Berle \& Means in 1932; they observed that there is separation between ownership and control in larger corporation, as a result of dilution in equity position. The theory tries to resolve the conflicts between owners and managers over the control of corporate resources through the use of contracts that seek to allocate decision rights and incentives. According to Roy \& Li (2002), the contractual device suggested by agency theory to accomplish the transfer of wealth from the organization to investors is debt creation. But, the use of debt by firms leads to agency costs. Debt agency cost arises due to conflict of interest between debt providers on one side, shareholders and managers on the other side (Jensen \& Meckling, 1976). The use of debt by firms, bond mangers promises to pay out future cash (Jensen, 1986). When a firm has debt, conflicts of interest arise between share and bond holders. As a result, shareholders are tempted to follow self seeking strategies. These conflicts of interest impose agency cost in the company, with the firm manager being likened to agent while debt holders and shareholders are the principals. In most cases, the agent may decide not to maximize the principal wealth. But since debt has to be paid in cash debt invariably reduced the amount of Cash flow derived by managers (Jensen, 1986). It also serves as a mechanism to discipline managers from engaging in self serving activities e.g prerequisite consumption, empire building etc and also provide the means for controlling the opportunistic behavior of managers by reducing the cash flow available for discretionary spending (Roy \& Li, 2002). As a result, manager's attention would be clearly focused on those activities that are likely to ensure that debt payments are made, rather than indulging in prerequisite and choosing only inputs and outputs that satisfies their own desire (Abor, 2008). This is so because managers may choose to invest on projects that may tend to reduce the firm's value but enhances their control over resources. For instance, Abor, (2008) and Ham \& Kent (2005) argued that managers may choose to continue operation to enhance their position 
even though it may be optimal for investors to liquidate the firm. This was corroborated by Harris \& Raviv(1990) that managers have an incentive to continue a firm's current operation even if shareholders prefer liquidation.

Researchers have suggested ways to resolve the agency conflicts problem. For instance, while Jensen and Meckling (1976) suggested that the use of secured debt might reduce the agency cost of debt, Barnea et al (1980) proposed that the agency problem associated with information asymmetric, shareholder risk incentive and foregone opportunities can be resolved by means of the maturity structure and call provision of the debt. Beyond this, the use of short term sources of debt may mitigate the agency problem (Bufena, Kenbata and Lynn, 2005). This, according to him is so because any attempt by shareholders to extract wealth from debt holders is likely to hinder the firm's access to short term debt in the near future. On the contrary, Jensen argued that debt is less effective in reducing agency cost in rapidly growing organization with large and profitable investment projects, but no free cash flow (Jensen, 1986). However, Roy \& Li (2002), have criticized the agency theory owing to its inability to take competitive environment into consideration or consider managers necessity to make choices beyond shareholders wealth maximizing perspective. According to them, this forms a serious omission for two reasons; first, some debt and equity represent different constituencies with their own competing and often mutually exclusive goals. Also, as the level of debt increases, the corporate governance structure can change from that of internal control to external control. Hence, the agency theory offers a good justification for firm to increase the amount of debt in the capital structure, as debt act as a disciplinary guide to company managers.

\section{The pecking order theory}

The pecking order theory was proposed by Myer \& Majluy(1984), by explaining the effect of information asymmetries between insiders and outsiders of companies. According to the theory, firms prioritize their financing sources such that all internal funds are exhausted first before looking elsewhere. According to the theory, firms would prefer internal sources of funds to costly external finance it will follow the pecking order of securities-from safe to risky debts, convertibles and other quasi equity instruments before equity. This order of preferences reflects the relative costs of various financing options. Clearly, firms would prefer internal sources to costly external finance (Myers \& Majluf, 1984; Myer, 1984). Hence, more profitable firms would use less debt than less profitable ones. In addition to Myer's evidence, numerous studies such as Fama \& French (2002); Shyam-Sunder \& Myer (1999); Allen (1993) also lend credence to the pecking order theory. They found that leverage is inversely related to profitability. However, the pecking order theory has been criticized by Goyal \& Frank (2003) who argued that the theory fail to hold for small firms where information asymmetric is presumably an important problem.

\section{Empirical Framework}

Several firm specific and non specific factors have been found to influence capital structure choices, some of these factors are:

Firm size: Size has been found to be a major determinant of a firm's capital structure. For instance, it is argued that smaller firms find it costly to resolve information asymmetric with lenders and financiers (Costanias, 1983).As a result, they find it difficult to obtain capital and in most cases, are offered capital at higher cost. According to Abor (2008), lenders to larger firms are more likely to be repaid than those to small firms, thereby reducing the agency cost associated with debt. Also, business financing is associated with transaction cost which is a function of scale and varies according to firm sizes. Smaller firms have higher transaction cost when issuing long term debt or equity (Titman \& Wessel, 1988). Empirical evidences presented by Barclay, Michael \&Smith (1996), Barton et al (1989), Hovakimian, Hovakimian \& Tehranian (2004), all support a positive relationship between firm size and leverage while studies such as while studies such as Chittenden, Hall \& Hutchinson (1996) and Fluck, Holtz-Eakin \& Rosen (2000) reports a negative relationship between firm size and short term debt ratio.

Asset structure: According to Harris \& Rajan (1991); Titman \& Wessel, (1988), the firm's liquidity value depends on the degree of tangibility of her assets. Firms with tangible assets can easily stake part of their assets as collateral for loans. Studies such as Storey (1994);Bradley, Jarrel \& Kim(1984); Berger \& Udell (1998); Wedig et al, (1988) all lend credence to the fact that firms with highly tangible asset borrow easily from banks. Hence, a positive relationship is expected between asset structure and debt ratios. Empirical studies by Bradley, Jarrel \& Kim(1984); Friend and Lang (1988); Abor, (2008); Mackie- Mason (1990); Havakimian, Hovakimian \& Tehranian (2004) Myer and Magluf (1984) all point to a positive relationship between asset structure and firm's leverage. Other studies such as Michaelas, Chittenden \& Poutziouris (1999); Hall, Hutchinson \& Michaelas (2004); Cassar and Holmes, (2003); Jordan, Lowe \& Taylor (1998) also suggest a positive relationship between asset structure and long term debt and a negative relationship between asset structure and short term debt. Also, Esperanca, Ana \& Mohammed (2003) also found a positive relationship between asset structure and both long and short term debt. 
Profitability: The pecking order theory forms the best tool to explain the relationship between firm's profitability and capital structure. In line with the theory, firms prioritize their financing such that internal equity is first exhausted before seeking external finances. This arises because profitable firms have access to large unused retained earnings that are readily available for future investment. According to Murinde et al (2004), retained earnings formed the principal source of finance. Barton et al (1989) proposed that high profitable firms would maintain low debt ratio since they have access to retained fund. But, Jensen (1986) argued that the existing relationship between leverage and profitability depends on the effectiveness of the market for corporate control. Empirical evidences presented by Barton et al (1989); Michael,Chittenden \& Poutziouris (1999); Mishra \& McConaughty (1999);Jordan, Lowe \& Taylor (1998);Chittenden, Hall \& Hutchinson (1996) all support a negative relationship between profitability and capital structure. Others such as Petersen \& Rajan (1994) found a significantly positive relationship between profitability and debt ratio.

Age of the firms. This refers to the number of years of the firm's existence in business. Since age is associated with experience, the longer the firm is in business, the greater her probability of accessing external financing at lower interest rate. According to Abor (2008), banks tend to evaluate the credit worthiness of enterprises before granting them loan. Also, long standing firms have enough tangible assets to pledge as collateral for loans. This is true in developing countries where majority of bank finances are tied to collateral securities, due to high rate of loan defaults. Empirically, there have been variations on the findings of studies relating firm's age to capital structure. While Hall, Hutchinson \& Michaelas (2004) posited that age is positively related to long term debt but negatively related to short term debt, Esperanca, Ana \& Mohammed (2003) found that age is negatively related to both long and short term debt.

Firm Risk: Firm level of risk has been found to be one of the determinants of capital structure. Castanias (1983) documented that the tax shelter- bankruptcy cost theory of capital structure determines a firm's optimal leverage as a function of business risk. Hence, the level of risk and the rate by which firms undertake riskiest investment is likely to affect her financing choices. A firm with high degree of business risk has been found by Kim \& Sorensen (1986) to have less capacity to sustain financial risks and hence, uses less debt. Empirical research on the relationship between firm risk and capital structure has yielded mixed results. For instance, while studies such as Esperanca, Ana \& Mohammed (2003); Bradley, Jarrel \& Kim(1984); Friend \& Lang (1988); Kale, Thomas \& Ramirez (1991); Titman \& Wessel (1988) shows an inverse relationship between risk and debt ratios, Jordan, Lowe \& Taylor (1998) and Michaelas,Chittenden \& Poutziouris (1999) shows a positive relationship.

Taxation: The effect of taxation on corporate capital structures have been undertaken by numerous studies. While some such as Shum (1996) \& Graham (1999) centered on tax policy, others such as MackieMason (1990) examined the tax effect on corporate financing decisions. The later concluded that a firm with high tax shield is less likely to be finance with debt because such tax shield lower the effective marginal tax rate on interest deduction. But, Graham (1999) argued that even though taxes do affect corporate financial decisions but that the magnitude of such effect is mostly "not large".

Firm's intention to grow and growth opportunity: Intention to grow and growth opportunities affect capital structure of a firm by influencing the agency cost associated with financing. According to Hall, Hutchinson \& Michaelas (2004), growth is likely to place a greater demand on internally generated funds and push the firm into borrowing. There is also a relationship between previous and future growth. For instance, Michaelas, Chittenden \& Poutziouris (1999) posited that future growth opportunities will be positively related to leverage; in particular, short term leverage. They also found future growth as relating positively to long term debt, Hall, Hutchinson \& Michaelas (2004) and Jordan, lowe and Taylor (1998) found mixed evidence. Also, empirical evidences in support of the relationship between growth and leverage seem contradicting. While researchers such as Titman and Wessel (1988); Barton et al (1989) found a positive relationship between sales growth and leverage, others such as kim \& Sorensen (1986); Rajan \& Zingale (1995); Al-Sakran (2001) reported that higher growth firms are associated with less debt.

Dividend Payout: Firms' financial leverage depends to a larger extent on the amount of dividend distributed to shareholders at the end of the business year of companies. While the bankruptcy cost theory suggest a negative relationship between dividend payout ratio and debt level, the pecking order shows a positive relationship. According to the former, low dividend payout ratio implies increase equity base for debt capital, hence, low tendency to go into liquidation. As a result, the bankruptcy cost is low. This invariably implies a high level of debt in the capital Structure. In the latter's view, since firms always prefer internal financing to high , expensive external debts, management would prefer to finance her activities through retained earnings. Consequently, a lower dividend payment ratio signals a lower level of debt in the capital structure.

\section{MATERIALS AND METHODS}

The study area is Nigeria which is one of the African countries situated in West Africa. It lies between Latitude $4^{0}$ to $14^{0}$ North and between Longitude $2^{0} 2^{1}$ and $14^{0} 30^{1}$ East and has a total population of 140,003,542 (NPoC, 
2006) and land area of approximately 923,708sq km (FOS, 1989). Data for the study were collected from the financial statements of twenty eight agro allied firms which have been listed in the Nigerian Stock Exchange (NSE) for the period 2005-2010. Data were analyzed using both descriptive and inferential statistics. The inferential statistics used was ordinary least squares multiple regression model. This was used to analyze those variables that affect short and long term debt ratios. The empirical investigation model for the listed agro allied firms is given as follows:

$\mathrm{SDR}=\beta_{0}+\beta_{1} \mathrm{PRFT}+\beta_{2} \mathrm{AST}+\beta_{3} \mathrm{SZ}+\beta_{4} \mathrm{GWT}+\beta_{5} \mathrm{TX}+\beta_{6} \mathrm{AGE}+\beta_{7} \mathrm{DIV}+\beta_{8} \mathrm{FRSK}+\epsilon \ldots \ldots$ (1)

$\mathrm{LDR}=\beta_{0}+\beta_{1} \mathrm{PRFT}+\beta_{2} \mathrm{AST}+\beta_{3} \mathrm{SZ}+\beta_{4} \mathrm{GWT}+\beta_{5} \mathrm{TX}+\beta_{6} \mathrm{AGE}+\beta_{7} \mathrm{DIV}+\beta_{8} \mathrm{FRSK}+\epsilon \ldots \ldots \ldots$ (2)

Where; SDR = short term debt ratio for the firm ( i.e short term debt/ equity+ debt)

$\mathrm{LDR}=$ long term debt ratio for the firm (i.e long term debt/ equity +debt)

PRFT $=$ Profitability: Proxied by the ratio of earnings before interest and taxes (EBIT) to the book value of total assets for the firm

AST $=$ Asset structure of the firm. This was measured by the ratio of tangible fixed assets to total assets for firm

$\mathrm{SZ}=$ size of firm measured by the natural log of total assets

$\mathrm{AGE}=$ number of years in business

GWT $=$ Growth rate in total sales for firm measured by the percentage change in the value of assets of firm i in time $\mathrm{t}$

TX =The ratio of Tax paid to operating income for firm

DIV =Dividend payable as a proportion of operating income for the firm: proxied as a ratio of dividend to total income available to shareholders. It is taken here to imply only cash and not stock

$\mathrm{FRSK}=$ Absolute coefficient of variation in earnings before interest and tax i.e $\partial \mathrm{EBIT} / \mu \mathrm{EBIT}$

Where $\partial \mathrm{EBIT}=$ expected earnings before interest and tax

$\mu \mathrm{EBIT}=$ the standard deviation of earnings before interest and tax

$\mathrm{C}=$ the error term

Also, all measures of capital structures were scaled by the book value of total assets.

\section{RESULTS AND DISCUSSION}

\section{Determinants of short term debt ratios of listed agro-allied firms}

Table 1 reports the estimate of the four functional forms of the short term debt ratio equation for listed agro allied firms in Nigeria. Based on the significant of the estimated independent variables and the high $\mathrm{R}^{2}$ value, the semi $\log$ model was chosen as the lead equation. The diagnostic test result shows $\mathrm{R}^{2}$ of 0.757 , implying that about 75.5 percent of the adjusted total variation in short term debt ratio is explained by the estimated independent variables. The F- statistics value of 5.44 is significant at 1 percent level, showing that the estimated $\mathrm{R}^{2}$ is significant and denote goodness of fit of the estimated model. The RESET and normality tests were significant at 10 percent probability level, indicating that the functional form is not mis-specified. From the empirical evidence, the coefficient for size was positive and significant at the 1 percent level of significance. This entails that large sized firms depend on short term debts for their finances. Large sized firms are perceived to have enough tangible assets at their disposal to pledge as collateral and access debt capital. This finding contradicts those of Buferna et al,(2010), Chittenden et al, (1996), Rosen et al, (2000), Miscaelas et al, (1999) and Scerr et al, (19930 who reported a negative relationship between firm size and short term debt ratio.

The coefficient of asset structure was also significant at 1 percent level of probability and positively related to short term debt ratio. This shows that highly tangible firms also use more short term debts. High tangible assets reduces the magnitude of debt loss incurred by debt providers should the firm default. Studies such as Burferna et al (2010) and Esperanca et al (2003) also reported a positive significant relationship between asset structure and short term debt ratio. It also contradicts the empirical findings from previous researches such as Joshua, (2008), Delek et al, (2009), Hall et al, (2004), Danbolt, (2002), Jordan et al, (1998) etc who reported a negative relationship between asset structure and short term debt ratio.

The estimated parameter for growth was positive and significant at 5 percent level, showing that growing listed firms use more short term debts, presumably due to their huge capital requirement for financing new short term investment opportunities and the need to meet current liabilities and other overhead expenses. Growing firms are presumed to lack both tangible assets and cheap long term credit sources of information and as such depends mostly on short term debts. This result support Burferna, et al (2010) and Abor,(2008). It also contradicts the theoretical predictions of Titman and Wessel (1988), Rajan and Zingales, (1995), Chung (1993) who reported a negative relationship between growth and level of debts on data from developed countries.

The result further revealed that the coefficient for tax had a significant positive relationship with short term debt ratio at 1 percent level of significance. This implies that agro listed firms with high taxes use more 
short term debts in their finances. This finding is consistent with Abor, (2008).

The profitability coefficient was negative and significantly related to short term ratio at 5 percent level, meaning that highly profitable firms do not depend on short term debts. The suitable explanation for this is that highly profitable firms are perceived to be liquid enough as to finance their short term investment through retained earnings at the expense of taking short term debts. This support the pecking order view that debt is only issued when there is insufficient retained income to finance investment (Fama and French,(1988), Allen,1993). This findings corroborates that of Jiang and Rogers (2005), Abor (2008), Hall et al,(2004). It also contradicts Voulgaris et al (2004) in Greece.

Table 1:Determinants of short term debt ratio equation of listed agro-allied firms

\begin{tabular}{|c|c|c|c|c|}
\hline Variable & Linear & Exponential & Semi log (L) & Double log \\
\hline Constant & $0.152 \quad(0.2170)$ & $-2.8764(-1.3425)$ & $0.2884(0.1461)$ & $-2.9344(-0.4716)$ \\
\hline Size & $-0.0047(-0.1133)$ & $0.0239(0.1897)$ & $0.4397(03.6579) * * *$ & $1.5364(1.7292)^{*}$ \\
\hline Asset St. & $0.5315(1.5290)$ & $1.6027(1.5106)$ & $0.3041(3.4017 * * *$ & $0.7423(2.6337)^{* *}$ \\
\hline Profitability & $0.3745(2.5115) * *$ & $=1.0673(2.3449)^{* * *}$ & $-0.2138(-2.4019)^{* *}$ & $0.4440(-2.4019)^{* *}$ \\
\hline Growth - & $-0.0549(-0.7458)$ & $-0.1501(-0.6681)$ & $0.0391(2.6125) * *$ & $-0.2212(0.3500)$ \\
\hline Dividend & $0.4541(1.4003)$ & $0.6503(0.6570)$ & $0.0468(0.9176)$ & $0.1995(1.2419)$ \\
\hline Risk & $-0.0984(-0.2670)$ & $-0.2015(-0.1792)$ & $-0.0535(-1.3541)$ & $0.1256(1.0094)$ \\
\hline Tax & $0.2297(0.9954)$ & $0.6995(0.9931)$ & $0.01299(3.3481)^{* * *}$ & $0.0108(1.9092)^{*}$ \\
\hline Age & $-0.0040(-1.0151)$ & $-0.0141(-1.1633)$ & $-0.050(-0.4529)$ & $-0.2048(-0.5862)$ \\
\hline $\mathrm{R}^{2}$ & 0.706 & 0.602 & 0.757 & 0.652 \\
\hline Fstat & 5.695 & 3.586 & 5.445 & 3.279 \\
\hline Norn Test & 1.497 & 1.748 & 1.964 & 2.206 \\
\hline RESET & 1.389 & 6.509 & 0.164 & 0.521 \\
\hline Akaike criteri & ion 30.01 & 96.16 & 25.82 & 78.63 \\
\hline Hetero test & 15.168 & 16.865 & 14.573 & 14.899 \\
\hline Schwarz crites & rion 42.00 & 104.49 & 33.47 & 86.2 \\
\hline
\end{tabular}

Note: $*=$ significant at $10 \%, * *$ significant at $5 \%, * * *$ significant at $1 \%$

However, age of the firm and business showed an inverse relationship with short term debt ratio. The negative relationship of age might be that older firms prefer long term debt at the expense of short term debts. This corroborates Hall et al (2004) and Esperanca et al (2003). As for business risk, the negative relationship is that firms with high risky investments are cautious in taking in more debts so as to reduce heavy financial pressure. This negative relationship of business risk contradicts Esperanca et al, (2003).

\section{Determinants of long term debt ratios of Agro listed firms}

Table 2 shows the estimate of various forms of long term debt equations for unlisted agro allied firms in Nigeria. The exponential form was chosen as the lead equation due to the high estimated $\mathrm{R}^{2}$ value as well as the conformity of the estimates to a priori expectations. The result of the diagnostic test revealed $\mathrm{R}^{2}$ value of 0.805 , indicating that the specified independent explanatory variables explain about 80.5 percent of the total variability in long term debt ratio. The F- statistics of 4.13 , significant at one percent depicts the significance of the estimated $\mathrm{R}^{2}$ and the goodness of fit of the estimated model. The RESET and normality tests were significant, justifying the appropriateness of the Ordinary Least Square regression technique used. It also shows that the functional form is not mis-specified.

From the empirical result, the profitability coefficient exhibited a negative and significant relationship with long term debt ratio, indicating that highly profitable firm uses less long term debts. This may imply that profitable firms have enough internally generated funds for their financing needs at the expense of borrowing. They tend to seek for costly external financing after exhausting their internal sources, thus, supporting the pecking order theory (POT) (see Ang, 1991). Similar results were reported by Joshua (2008), Hall et al (2004), Barton et al (1989), Mishra and McConnaughty (1999), Jordan et al (1998) and Chittenden et al (1996).

The size coefficient was positive and significantly related to long term debt ratio at one percent, showing that large sized firms depend on long term debt for their finances. This result conform to a priori expectation because large sized firms with high tangible assets are known to access credits easier than smaller firms with lack of tangible assets with which to secure long term debts. This is true, especially in developing countries where debt providers require collateral due to high rate of loan defaults. Also, Um,(2001) reported that larger sized firms use more debts because of lower debt monitoring cost. In his opinion, firm size may proxy for the debt agency costs arising from conflicts between managers and investors. Beside, large sized firms are viewed by Bevan and Danbolt,(2002) to be regarded by debt providers as " too big to fail" and as a result tend to 
be given more debts. This finding lend support to those of Anthonious et al, (2002), Hovakiman et al, (2004), Bevan and Danbolt, (2002), Al- Sakran, (2001), Jian and Rogger (2005), Barton et al (1989), Holtz- Eakn and Kim et al (1998), Barclay and Smith (1998).

The coefficient for age was positive and significant at ten percent level of probability, implying that older listed firms depend on long term debts for their finances. This is surprising given that over time, old listed firms are often expected to be in a position to attract more equity investors and as such uses more equity at the expense of debts. It might also be that, older firms with their knowledgeable credit sources information know where to secure cheaper long term debts at concessionary interest rates and less stringent debt conditions than start up firms and patronize them. Another possible explanation is that older listed firms have over the years accumulated enough tangible assets that can be used as security to secure long term debts than new firms. This finding contradicts that of Abor,(2008) who reported a negative significant relationship between age and long term debt ratio for quoted firms in Ghana and support Peterson and Rajan, (1994).

The estimated coefficient for growth was positive and significant at ten percent probability level, implying that growing firms use more long term debts. It can be argued that growing firms requires huge long term capital for financing their growth and new investment opportunities such as business expansion, procurement of tangible assets as well as meeting current expenditures. This findings corroborates that of Abor,(2008), Michaelas, Chittenden and Poutziouris, (1999).

The empirical findings further revealed that asset structure significantly influence long term debt ratio at ten percent probability level. This is in line with previous studies. Firms with high tangible assets are perceived to use more long term debts. They tend to mortgage such tangible assets as collateral for debt providers and accesses long term debts. This findings support previous studies such as Bevan and Danbolt, (2000 and 2002) in United Kingdom, Wuri,(2000) in Korea, Abor,(2008) in Ghana, Wiwattanakantang (1999) in Thailand and Um, (2001) in Korea.

Table 2: Determinants of long term debt ratio equation of listed agro-allied firms

\begin{tabular}{|c|c|c|c|c|}
\hline Variable & Linear & Exponential(L) & Semi log & Double $\log$ \\
\hline Constant & $0.3162(0.4804)$ & $-3.8613(-1.2294)$ & $1.1348(0.5658)$ & $-3.5714(0.5658)$ \\
\hline Size & $-0.0175(-0.4521)$ & $0.0201(3.1104) * * *$ & $0.0287(0.0423)$ & $1.8821(0.6217)$ \\
\hline Asset St. & $0.5457(1.9743)^{*}$ & $2.7101(1.7425)^{*}$ & $0.2575(2.8347)^{* *}$ & $0.8374(2.0677)^{*}$ \\
\hline Profitabil & ity $0.2332(1.998)^{*}$ & $-1.43985(-2.1580) * *$ & $0.1253(1.3850)$ & $0.3964(0.9832)$ \\
\hline Growth & $-0.0314(-0.4556)$ & $0.0526(1.9597)^{*}$ & $0.0328(0.5056)$ & $0.1011(0.3500)$ \\
\hline Dividend & $0.4509(0.1545)$ & $0.1301(0.0896)$ & $0.0452(0.8735)$ & $0.1233(0.5341)$ \\
\hline Risk & $0.1350(0.3910)$ & $-0.3433(-0.2083)$ & $0.0659(1.6422)$ & $0.2635(1.4735)$ \\
\hline Tax & $0.0879(0.4060)$ & $0.4606(0.4461)$ & $-0.0305(-0.8098)$ & $0.0552(-0.3287)$ \\
\hline Age & $-0.0049(-2.3210)^{* *}$ & $0.03465(1.9481)^{*}$ & $-0.0316(-0.2805)$ & $-0.4304(-0.8575)$ \\
\hline $\mathrm{R}^{2}$ & 0.689 & 0.805 & 0.738 & 0.654 \\
\hline Fstat & 6.09 & 4.131 & 4.949 & 3.305 \\
\hline Norn Tes & 3.007 & 0.763 & 5.182 & 10.19 \\
\hline RESET & 0.335 & 5.0790 & 2.6463 & 0.0798 \\
\hline Akaike cr & riterion 26.40 & 113.91 & 23.98 & 92.74 \\
\hline Hetero te & st $\quad 14.253$ & 15.35 & 14.59 & 15.75 \\
\hline Schwarz & criterion 38.39 & 125.90 & 34.19 & 102.98 \\
\hline
\end{tabular}

Note: $*=$ significant at $10 \%, * *$ significant at $5 \%, * * *$ significant at $1 \%$, L denote the lead equation

\section{Recommendation and Conclusion}

Based on the result, it is important for policy to be directed at improving the information environment. Firms should be encouraged to maintain proper records and policy makers should place greater emphasis on the facilitation of equity capital since it provides a base for further borrowing while reducing business sensitivity to economic cycles. Considering that large firms have easier access to finance, firms should consider entering the international markets and sole-proprietorship should be encouraged to consider more organized forms of business. Finally, further research should be carried out to examine determinants of capital structure of unlisted agro-allied firms in Nigeria for comparism incognizance of the economic and technological level of the country.

The study therefore concluded that capital structure choices is an important financial decision for every firm be it agro or non agro-based. It is a complex decision that is affected by several firm specific and non specific factors. These factors have been identified by the research and several policy measures required in ensuring that appropriate capital structure decisions are advanced. The research has shown the importance of size 
and tangible assets in securing long term debts. It has also shown the importance of short term debts over long term debts in the agro firms under investigation. The result suggests that the pecking order theory dominates the financing behavior of listed agro allied firms in Nigeria. The result of this study has also contributed towards a better understanding of how listed agro allied firms in Nigeria finance their operations. It is hoped that the policy implications in this study will be of immense benefits to policy makers, managers and scholars on issues pertaining to financing decisions of agro allied firms in Nigeria. Further research should be carried out to examine the determinants of capital structure of unlisted agro allied firms in Nigeria.

\section{REFERENCES}

Abel E. E. (2011). Firms versus Industry Financing Structure in Nigeria. African Journal of Economic and management studies Vol.2, issue 1, pp 42-55.

Abor, J. (2004). Internationalisation and financing Options of Ghanaian SMEs. Acta Commercii, 4: 60-72

Abor, J. (2008). Determinants of the Capital Structure of Ghanaian Firms. Research Paper 176 African Economic Research Consortium, Nairobi

Al-Sakran, S.A. (2001). Leverage determinants in the absence of corporate tax system: The case of non-financial publicly traded corporations in Saudi Arabia. Managerial Finance, 27(10/11): 58-86.

Antoniou, A., Y. Guney and K. Paudyal (2002). Determinants of Corporate Capital Structure: Evidence from European Countries, Working Paper, University of Durham.

Arene, C. J. and S. O. Ndomadu (1992), "Impact of Value Added Tax on the Capital Structure and Profitability of Premier Breweries PLC, Nigeria.” VIKALPA, Vol 22 No 3 Pp71- 77.

Barclay, Michael J. and Clifford W. Smith, Jr.(1996). On financial architecture: Leverage, maturity and priority. Journal of Applied Corporate Finance, 8: 4-17.

Barnea, A., R.A. Haugen and L.W. Senbet.(1980). A rationale for debt maturity and call provision in the agency theoretic framework. The Journal of Finance, 35(5): 1223-34.

Barton, S.L., C.H. Ned and S. Sundaram.( 1989). An empirical test of stakeholder theory predictions of capital. Financial Management, 18(1): 36-44.

Bevan, A. and Danbolt, J.,(2002).Capital structure and its determinants in the UK- a decompositional analysi. Applied Financial Economics 12, 159-170.

Booth, L., V. Aivazian, A. Demirguc-Kunt and V. Maksimovic.( 2001).Capital structures in developing countries. Journal of Finance, 55(1): 87-130.

Buferna, Fakhner, Kenbata Bangassa, and Lynn Hodgkinson (2005). .Determinants of Capital Structure. Evidence from Libya. Research Paper Series, The University of Liverpool, 2005/08.

Castanias, R.(1983). Bankruptcy risk and optimal capital structure. The Journal of Finance, 38:1617-35.

Chen, J., 2004. Determinants of capital structure of Chinese-listed companies, Journal of Business Research 57, 1341-1351.

Cheng, Linda H., and Jiang, George J. (2001). The Determinants of Dutch Capital Structure Choice:SOM-theme E of Dutch Capital Choice.

Chittenden, F., G. Hall and P. Hutchinson. (1996). Small firm growth, access to capital markets and financial structure: Review of issues and an empirical investigation. Small Business Economics, 8: 59-67.

Esperança, J.P., P.M.G. Ana and A.G. Mohamed.( 2003). Corporate debt policy of small firms: An empirical (re)examination. Journal of Small Business and Enterprise Development, 10(1):62-80.

Fama, E. and French, K.R.,( 2002). Testing tradeoff and pecking order predictions about dividends and debt. The Review of Financial Studies, 15, 1-33.

Federal Office of Statistics (1989).Yearly Economic Review, December.

Fluck, Z.D holtz-Eakin and H.S. Rosen (2000).where does the money come from?. The financing of small entrepreneurial enterprises.Working paper, New York Un iversity.

Goyal, Vidhan K., and Murray Frank (2003). Testing the pecking order theory of capital Structure. Journal of Financial Economics, 67 (2), 217-248.

Graham J.R., (1996). Debt and the marginal tax rate. Journal of Financial Economics 41, 41-73.

Green, C.J., V. Murinde and J. Suppakitjarak.( 2002). Corporate Financial Structure in India.Economic Research Paper No. 02/4. Centre for International, Financial and Economics Research, Department of Economics, Loughborough University, Loughborough.

Hall, G.C., P.J. Hutchinson and N. Michaelas.( 2004). Determinants of the capital structures of European SMEs. Journal of Business Finance and Accounting, 31(5/6): 711-28.

Harris, M. and A. Raviv.( 1991). The theory of capital structure. Journal of Finance, 46(1): 297-355.

Hovakimian, A., G. Hovakimian and H. Tehranian.( 2004). Determinants of target capital structure:The case of dual debt and equity issues. Journal of Financial Economics, 71: 517-40.

Ijaiya, G.T.(2000). Economic Growth in Nigeria An Asymmetry of the Balanced Growth Doctrine. In Usman A and Ijaiya, G. T (eds.) Selected Essays on the Contributions of Economic Development Theories in 
Nigeria, Illorin: Haytee Publishing Co.

Iwayemi, A. (1994).Perspectives and Problems of Economic Development in Nigeria: 1960-1990. Ibadan: CEAR.

Iwarere, H. T and Akinleye, G. T (2010).Capital Determinants in the Nigerian Banking Industry: Financial manager's perspective. Pakistan Journal of social sciences, Vol.7 (3) pp 205-313.

Jensen, M.,(1986). Agency costs of free cash flow, corporate finance and takeovers. AmericanEconomic Review, 76, 323-329.

Jensen, M. and W. Meckling (1976). Theory of the firm: Managerial behavior, agency costs and ownership structure. Journal of Financial Economics, 3: 305-60.

Kayhan, A. \& Titman, S,(2007). Firm' history and their capital structures. Journal of Financial Economics, 83, $1-32$.

Kim, W.S. and E.H. Sorensen.( 1986). Evidence on the impact of the agency costs of debt on corporate debt policy. Journal of Financial and Quantitative Analysis, 21: 131-43.

Mishra, C.S. and D.L. McConaughy.(1999). Founding family control and capital structure: The risk of loss of control and the aversion to debt. Entrepreneurial Theory and Practice, 23:53-64.

Murinde, V., J. Agung and A.W. Mullineux.( 2004). Patterns of corporate financing and financial system convergence in Europe. Review of International Economics, 12(4): 693-705.

Myers, S.C.(2001). Capital structure. Journal of Economic Perspectives, 15(2): 81-102.

Myers, S.C. and N.S. Majluf.(1984). Corporate financing and investment decisions when firms have information that investors do not have. Journal of Financial Economics, 13: 187-221.

National Population Commission (2006). Census Report, Abuja, Nigeria

Oyedipe, A.A (2001). Agricultural Research Policy and National Development. A paper presented at the Inhouse Technical Workshop for the Agricultural Research Institute on the Agricultural Policy, Abuja, $10^{\text {th }}$ April.

Pandey, I.,(1999). Finacial Management. India, Vikas Publishing.

Petersen, M.A. and R.G. Rajan(. 1994). The benefits of lending relationships: Evidence from small business data. The Journal of Finance, 49(1): 3-38.

Rajan, R.G. and L. Zingales. (1995). What do we know about capital structure: Some evidence from international data. Journal of Finance, 50: 1421-60.

Roy, L. Simerly and Mingfang, Li (2002). Rethinking the Capital Structure Decision. Available online at http://www.wesga.edu/bquest/2002/rethinking.htm.S

Shyam-Sunder, L. and S.C. Myers. (1999). Testing static tradeoff against pecking order models of capital structure. Journal of Financial Economics, 51: 219-44.

Shum, P.M.(1996). Taxes and corporate debt policy in Canada: An empirical investigation. Canadian Journal of Economics, 29(3): 557-72.

Singh, A.(1995). Corporate Financial Patterns in Industrializing Economies: A Comparative Study. IFC Technical Paper No. 2. International Finance Corporation, Washington, D.C.

Singh, A. and J. Hamid,(1992). Corporate Financial Structures in Developing Countries. IFC Technical Paper No. 1. International Finance Corporation, Washington, D.C.

Titman, S. and R. Wessels. (1988). The determinants of capital structure choice. Journal of Finance, 43(1): 119.

Umar, S, I. (2008). An Assessment of Agricultural and Non- Agricultural Livelihood Activities of Youth in kaboji Districts, Nigers State, Nigeria. Proceedings of the $10^{\text {th }}$ International Conference held at the University of Abuja.

Voulgaris, F., Asteriou, D., Agiomirgianakis, G.,(2004). Size and determinants of Capital Strucuture in the Greek Manufacturing Sector. International Review of Applied Economics, 18, 2, 247-262.

Yesufu, T. M. (1996). The Nigerian Economy Growth without Development: Benin Social Science Series for Africa. 
The IISTE is a pioneer in the Open-Access hosting service and academic event management. The aim of the firm is Accelerating Global Knowledge Sharing.

More information about the firm can be found on the homepage:

http://www.iiste.org

\section{CALL FOR JOURNAL PAPERS}

There are more than 30 peer-reviewed academic journals hosted under the hosting platform.

Prospective authors of journals can find the submission instruction on the following page: http://www.iiste.org/journals/ All the journals articles are available online to the readers all over the world without financial, legal, or technical barriers other than those inseparable from gaining access to the internet itself. Paper version of the journals is also available upon request of readers and authors.

\section{MORE RESOURCES}

Book publication information: http://www.iiste.org/book/

\section{IISTE Knowledge Sharing Partners}

EBSCO, Index Copernicus, Ulrich's Periodicals Directory, JournalTOCS, PKP Open Archives Harvester, Bielefeld Academic Search Engine, Elektronische Zeitschriftenbibliothek EZB, Open J-Gate, OCLC WorldCat, Universe Digtial Library, NewJour, Google Scholar

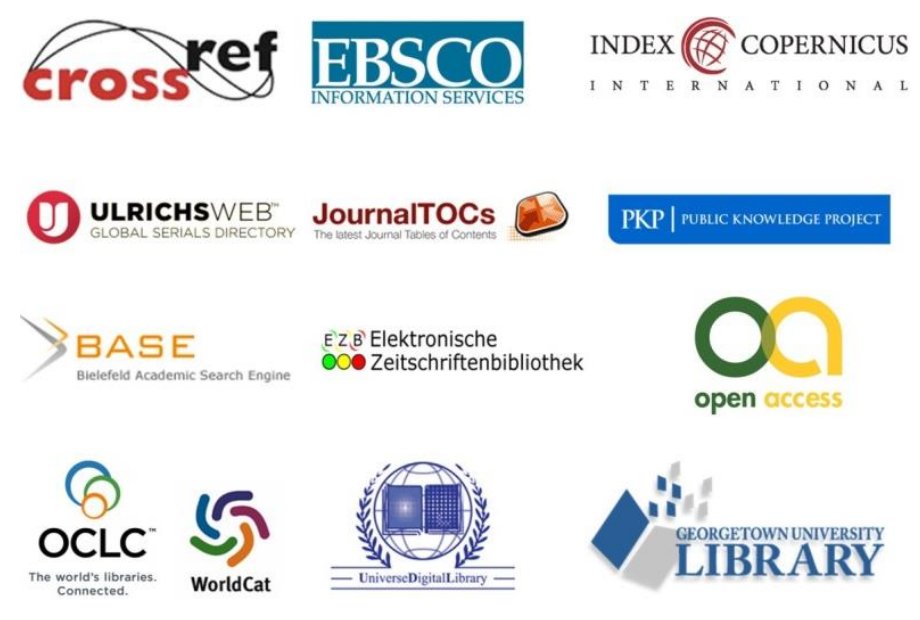

